\title{
Atrial natriuretic peptide enhances cortisol secretion from guinea-pig adrenal gland: Evidence for an indirect paracrine mechanism probably involving the local release of medullary catecholamines
}

\author{
DIPALI RAHA ${ }^{1}$, CINZIA TORTORELLA ${ }^{2}$, GIULIANO NERI ${ }^{2}$, ANITA PRASAD ${ }^{1}$, \\ BUSHRA RAZA $^{1}$, RANU RASKAR ${ }^{1}$, RAKHI DUBEY ${ }^{1}$, NISARGA S. SEN ${ }^{1}$, CARLO MACCHI ${ }^{2}$, \\ LUDWICK K. MALENDOWICZ ${ }^{3}$, M. FIROZ AHMAD ${ }^{1}$ and GASTONE G. NUSSDORFER ${ }^{2}$ \\ ${ }^{1}$ Department of Zoology, Ranchi University, Ranchi 834008, India; ${ }^{2}$ Department of Human Anatomy and Physiology, \\ Section of Anatomy, University of Padua, I-35121 Padua, Italy; ${ }^{3}$ Department of Histology and Embryology, \\ Karol Marcinkowski University of Medical Sciences, PL-60781 Poznan, Poland
}

Received November 7, 2005; Accepted December 18, 2005

\begin{abstract}
Atrial natriuretic peptide (ANP) is a regulatory hormone widely expressed, along with its receptors, in organs and body tissues. ANP is well known to inhibit aldosterone secretion from mammalian adrenals, but its effect on glucocorticoid-hormone production is controversial. In vivo experiments showed that prolonged ANP administration raised the plasma concentration of cortisol in both normal and dexamethasone/captopril-treated guinea pigs (i.e. in animals with pharmacologically interrupted hypothalamic-pituitaryadrenal axis and renin-angiotensin system). ANP did not affect cortisol secretion from dispersed guinea pig zona fasciculatareticularis cells, but enhanced catecholamine release from adrenomedullary cells. ANP stimulated cortisol output from guinea pig adrenal slices containing medullary chromaffin tissue, and the $\beta$-adrenoceptor antagonist $l$-alprenolol blocked this effect. The conclusion is drawn that ANP, when the structural integrity of the adrenal gland is preserved, is able to enhance glucocorticoid secretion in guinea pigs, through an indirect mechanism involving the rise in the catecholamine release, which in turn, acting in a paracrine manner, stimulate secretion of inner adrenocortical cells.
\end{abstract}

\section{Introduction}

Atrial natriuretic (ANP) is the first member of a family of peptides originally discovered in the late 1970s in the secretory

Correspondence to: Professor G.G. Nussdorfer, Department of Human Anatomy and Physiology, Section of Anatomy, Via Gabelli 65, I-35121 Padova, Italy

E-mail: gastone.nusdorfer@unipd.it

Key words: atrial natriuretic peptide, adrenal gland, corticosteroid secretion, catecholamine secretion, guinea pig granules of atrial myocytes, and including brain natriuretic peptide and C-type natriuretic peptide (reviewed in ref. 1). ANP acts via two G protein-coupled receptors, named A and B, that are coupled to guanylate cyclase (reviewed in refs. 2,3). Subsequent studies showed that ANP and its receptors are present in several extra-atrial tissues, among which are heart ventricles, blood vessels, brain, lungs, kidneys and endocrine glands.

Mammalian adrenal zona glomerulosa possesses A and B subtypes of ANP receptors, and many lines of evidence indicate that ANP, via the cyclic-GMP pathway, inhibits either basal or agonist-stimulated aldosterone secretion (reviewed in refs. 4,5). The possible effects of ANP on the zona fasciculata and glucocorticoid secretion have been far less investigated. Although ANF receptors have been demonstrated in the rat zona fasciculata (6), most studies did not report any effect of ANP on glucocorticoid secretion in this species $(1,4)$. However, findings suggest that ANP is able to lower basal and especially ACTH-stimulated glucocorticoid production from cultured human and cow zona fasciculata cells $(7,11)$. The A subtype of ANP receptors is expressed also in the adrenal medulla $(12,13)$, and the bulk of evidence indicates that ANP inhibits catecholamine release (14-17). However, ANP has been more recently reported to induce tyrosine hydroxylase mRNA expression and to raise catecholamine content in rat pheochromocytoma PC12 cells, via the guanylate cyclase-dependent cascade (18).

Therefore, it seemed worthwhile to investigate the in vivo and in vitro effects of ANP on glucocorticoid and catecholamine secretion from the guinea-pig adrenal gland. Guinea pig was chosen because its main glucocorticoid hormone is cortisol, as in humans and cows.

\section{Materials and methods}

Animals and reagents. Adult male guinea pigs, either bred in our laboratory facilities (in vivo experiments) or purchased from Charles-River (Como, Italy) (in vitro experiments), were 


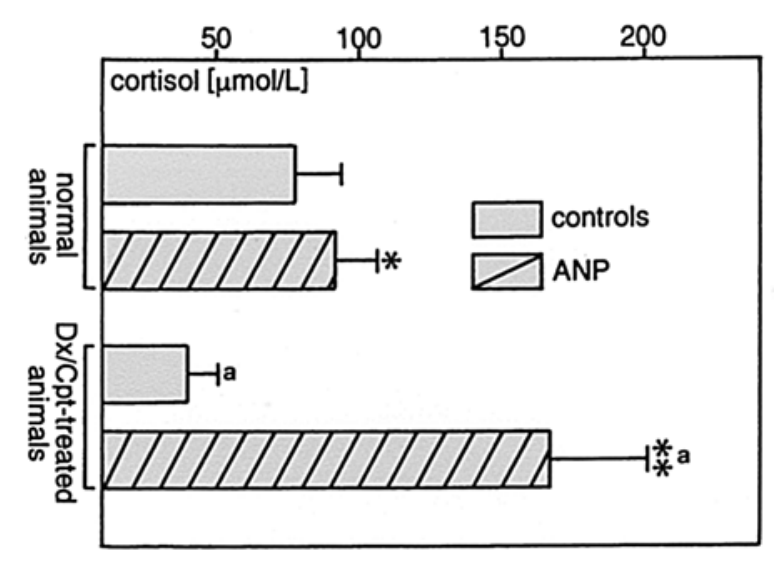

Figure 1. Effect of the prolonged administration of ANP on the blood concentration of cortisol in normal and dexamethasone (Dx)/captopril $(\mathrm{Cpt})$-treated guinea pigs. Bars are means \pm SEM $(\mathrm{n}=20) .{ }^{*} \mathrm{P}<0.05$ and ${ }^{* *} \mathrm{P}<0.01$ from the respective control group; ${ }^{\mathrm{a}} \mathrm{P}<0.01$ from the respective normal animal group.

kept under a 12:12 h light/dark cycle (illumination onset at 8:00 a.m.) at $23^{\circ} \mathrm{C}$, and maintained on a standard diet and tap water ad libitum. The study protocol was approved by the local Ethics Committees for Animal Studies. The angiotensinconverting enzyme inhibitor captopril (Capoten) was obtained from Squibb (Milan, Italy). ANP, ACTH, bovine serum albumin (BSA), and all other chemicals and reagents were purchased from Sigma-Aldrich Corp. (St. Louis, MO).

In vivo experiments. Animals were divided into two groups $(\mathrm{n}=40)$. One group was subcutaneously injected for 14 days with dexamethasone $(2.5 \mathrm{mg} / \mathrm{kg})$ and captopril $(2.5 \mathrm{mg} / \mathrm{kg})$. The other group was given daily injections of $0.9 \% \mathrm{NaCl}$. On the 6th day, half the animals in each group received ANP $(0.1 \mathrm{mg} / \mathrm{kg})$. At the end of the treatment, blood samples were collected from retro-orbital vein, and stored at $-30^{\circ} \mathrm{C}$ until hormonal assay.

In vitro experiments. Guinea pigs were sacrificed by cervical dislocation, and their adrenal glands were gently decapsulated to separate zona glomerulosa from the inner zones and then hemisected; adrenal halves were enucleated for removal of adrenal medulla. Dispersed zona fasciculata-reticularis and adrenomedullary cells were obtained by collagenase digestion and mechanical disaggregation, and the purity of cell preparations was checked under the phase microscope $(19,20)$. Freshly dispersed cells obtained from 6 guinea pigs were pooled to obtain a single cell suspension, and 6 cell suspensions for each incubation experiment were employed. Aliquots of each cell suspension $\left(10^{4}\right.$ cells $/ \mathrm{ml}$ in Krebs-Ringer bicarbonate buffer with $0.3 \%$ glucose and $0.2 \%$ BSA) were incubated with ANP (from $10^{-12}$ to $10^{-6} \mathrm{M}$ ), or in the absence of ANP (baseline value). Adrenocortical cells were also incubated in the presence of $10^{-8} \mathrm{M} \mathrm{ACTH}$. Adrenal glands from other guinea pigs were sliced, and slices (containing both cortical and medullary tissues; $6-8 \mathrm{mg}$ tissue $/ \mathrm{ml}$ ) were incubated, in replicates of 6 each, as follow: i) ANP (from $10^{-12}$ to $10^{-6} \mathrm{M}$ ); and ii) $l$-alprenolol $\left(10^{-6} \mathrm{M}\right)$ alone or in the presence of $10^{-8} \mathrm{M}$ ANP. The incubation was carried out in a shaking bath at $37^{\circ} \mathrm{C}$ for $60 \mathrm{~min}$ (cortisol secretion) or $20 \mathrm{~min}$ (catecholamine secretion),

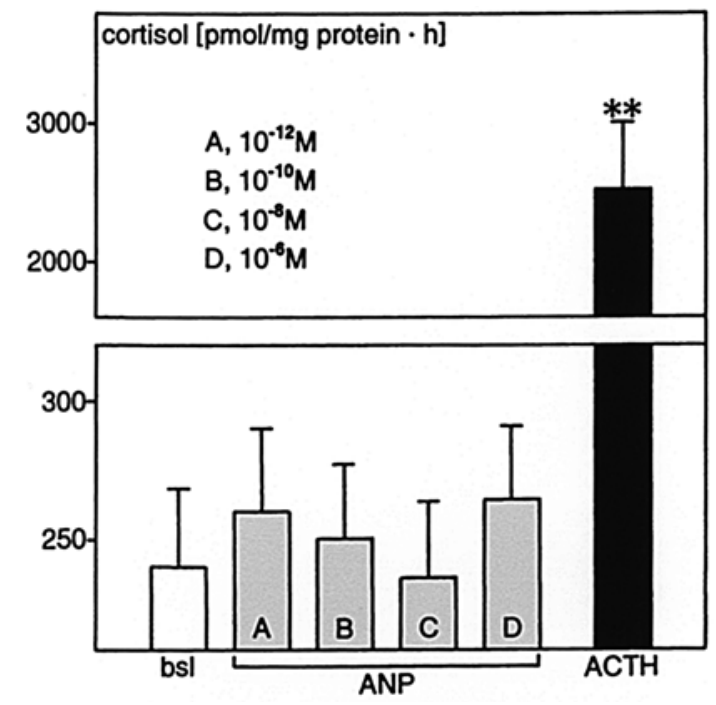

Figure 2. Effect on ANP and ACTH on cortisol secretion from dispersed guinea pig zona fasciculata-reticularis cells. Bars are means $\pm \operatorname{SEM}(n=6)$. ${ }^{* *} \mathrm{P}<0.01$ from baseline (bsl)

in an atmosphere of $95 \%$ air- $5 \% \mathrm{CO}_{2}$. Supernatants were stored at $-80^{\circ} \mathrm{C}$ until hormonal assays, and protein concentration of dispersed cells and tissue slices was measured by the BCA protein assay kit (Sigma-Aldrich Corp.).

Hormone assays. Cortisol blood concentration was measured by enzyme immunoassay (EIA), as previously detailed (21). Cortisol was extracted from supernatants and purified by HPLC (22-24), and its concentration was estimated by radioimmunoassay (RIA), using a commercial kit purchased from IRE-Sorin (Vercelli, Italy) (20). The catecholamine (epinephrine, E; and nor-epinephrine, NE) concentrations in the supernatants were measured by HPLC, using a reverse phase column and a glassy carbon electrochemical detector $(22,25,26)$.

Statistics. Data were expressed as means \pm SEM, and their statistical comparison was done by the paired sample t-test (cortisol blood concentration) or by ANOVA, followed by Duncan's multiple range test.

\section{Results}

The prolonged dexamethasone/captopril administration lowered by about $45 \%$ the blood concentration of cortisol in guinea pigs. ANP treatment for 6 days increased the plasma level of cortisol by about $20 \%$ in normal guinea pigs and by about 3.5-fold in dexamethasone/captopril administered animals (Fig. 1).

ANP did not affect cortisol secretion from dispersed guinea pig inner adrenocortical cells displaying a normal response to ACTH (Fig. 2). In contrast, ANP $\left(10^{-8}\right.$ and $\left.10^{-6} \mathrm{M}\right)$ enhanced E and NE release from medullary cells by about 3 -fold, lower concentrations of ANP being ineffective (Fig. 3).

ANP $\left(10^{-8}\right.$ and $\left.10^{-6} \mathrm{M}\right)$ raised cortisol production from guinea pig adrenocortical slices containing adrenomedullary tissue by about $45 \%$ (Fig. 4), as well as evoked a significant increase in $\mathrm{E}$ and $\mathrm{NE}$ release (data not shown). The cortisol 


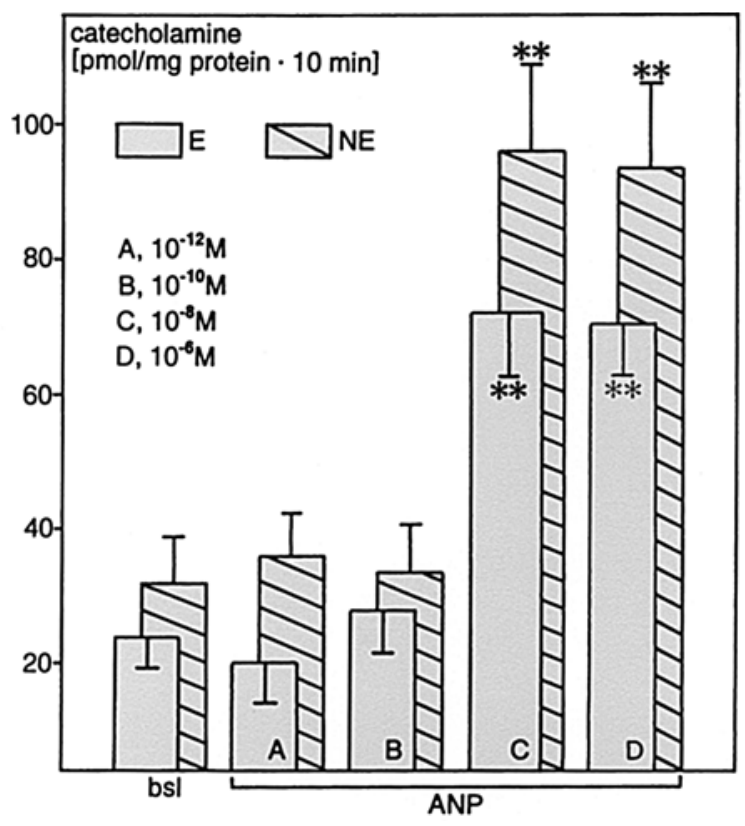

Figure 3. Effect of ANP on catecholamine secretion from dispersed guinea pig adrenomedullary cells. Bars are means \pm SEM $(n=6) .{ }^{* *} \mathrm{P}<0.01$ from baseline (bsl).

secretagogue effect of $10^{-8} \mathrm{M}$ ANP was annulled by $10^{-6} \mathrm{M}$ $l$-alprenolol, which per se was ineffective (Fig. 5).

\section{Discussion}

Our present in vivo experiments show that ANP is able to raise the blood level of cortisol not only in intact guinea pigs, but also in animals where the hypothalamic-pituitary-adrenal axis and renin-angiotensin system had been pharmacologically blocked by dexamethasone and captopril. This finding rules out the possibility that ANP effect was due to a stimulating action on ACTH and/or angiotensin II release, and strongly suggests that this peptide acts directly on the adrenal gland. However, a direct action of ANP on zona fasciculatareticularis cells can be excluded, inasmuch as this peptide does not exert any cortisol secretagogue effect on dispersed cell preparations. In this connection, we wish to stress that this last observation is at variance with the reported direct inhibitory effect of ANP on the secretory activity of inner adrenocortical cells of other cortisol-secreting species, like cows and humans (7-11). Despite ineffective on inner adrenocortical cells, ANP is able to stimulate cortisol secretion from guinea pig adrenal slices containing medullary tissue. Thus, it seems conceivable to postulate that an indirect effect, mediated by medullary chromaffin cells, underlies this cortisol secretagogue action of ANP. Compelling evidence indicates that catecholamines are able to stimulate steroidogenesis, adrenocortical cells being provided with $\beta$-adrenoceptors $(5,27)$. Several regulatory peptides have been reported to enhance steroid secretion by eliciting the release of catecholamines from chromaffin cells, that in turn stimulate adrenocortical cells acting in a paracrine manner: VIP and PACAP (reviewed in ref. 28), neuropeptide-Y (reviewed in ref. 29), tachykinins (reviewed in ref. 30), endothelins (reviewed in ref. 31), and adrenomedullin and related peptides (reviewed in ref. 32).

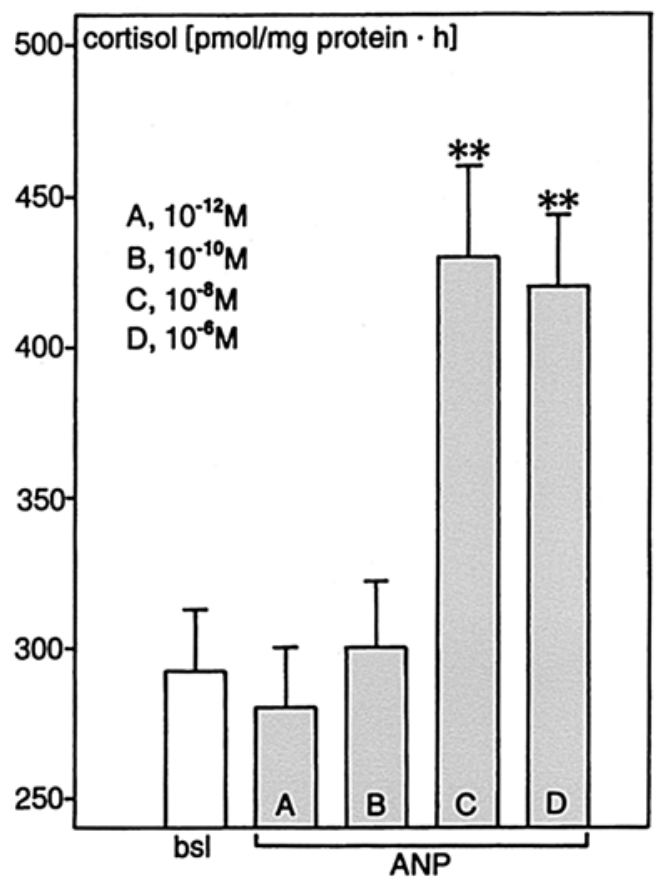

Figure 4. Effect of ANP on cortisol secretion from guinea pig adrenal slices containing medullary chromaffin tissue. Bars are means $\pm \operatorname{SEM}(n=6)$. ${ }^{* *} \mathrm{P}<0.01$ from baseline (bsl)

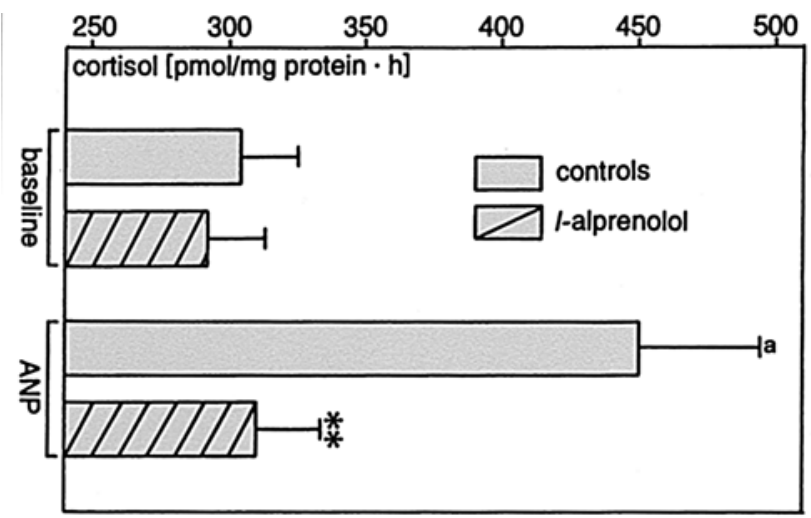

Figure 5. Effect of $l$-alprenolol $\left(10^{-6} \mathrm{M}\right)$ on baseline and $\operatorname{ANP}\left(10^{-8} \mathrm{M}\right)$ stimulated cortisol secretion from guinea pig adrenal slices containing medullary chromaffin tissue. Bars are means \pm SEM $(n=6) .{ }^{* *} \mathrm{P}<0.01$ from the respective control group; ${ }^{\mathrm{P}}<0.01$ from baseline.

The hypothesis that in guinea pigs the mechanism mediating the glucocorticoid secretagogue action of ANP involves an increased release of catecholamines is supported by the following evidence: i) ANP enhances E and NE release from guinea pig adrenomedullary cells, a finding stressing again the species-related differences between guinea pigs and cows, dogs and rats, where ANP appears to inhibit catecholamine release (14-17); and ii) $l$-alprenolol, a specific $ß 1$-receptor antagonist, completely suppresses cortisol response of guinea pig adrenal slices to ANP, without per se affecting baseline cortisol secretion. This last observation makes unlikely the possibility that the $l$-alprenolol effect was due to a nonspecific inhibitory effect on the steroidogenic machinery of inner adrenocortical cells. 
Collectively, our present findings allow us to draw the following conclusions: i) when the structural integrity of adrenal gland is preserved, ANP is able to stimulate glucocorticoid secretion in guinea pigs through an indirect paracrine mechanism involving adrenomedullary catecholamine release; and ii) relevant species-specific differences occur in the adrenal cytophysiology of guinea pig and other mammalian species, especially as far as catecholamine response of adrenomedullary cells to ANP is concerned.

\section{References}

1. Cantin $\mathrm{M}$ and Genest $\mathrm{J}$ : The heart and atrial natriuretic factor. Endocr Rev 6: 107-127, 1985.

2. Rosenzweig A and Seidman CE: Atrial natriuretic factor and related peptide hormones. Annu Rev Biochem 60: 229-255, 1991.

3. Silberbach M and Roberts CR Jr: Natriuretic peptide signalling. Molecular and cellular pathways to growth regulation. Cell Signal 13: 221-231, 2001.

4. Ganguly A: Atrial natriuretic peptide-induced inhibition of aldosterone secretion; a quest for mediator(s). Am J Physiol 263: E181-E194, 1992.

5. Nussdorfer GG: Paracrine control of adrenal cortical function by medullary chromaffin cells. Pharmacol Rev 48: 495-530, 1996.

6. Mulay S, Vaillancourt P, Omer S and Varma DR: Hormonal modulation of atrial natriuretic factor receptor in adrenal fasciculata cells from female rats. Can J Physiol Pharmacol 73: 140-144, 1995.

7. Higuchi K, Nawata H, Kato KI, Ibayashi $H$ and Matsuo H: Alfahuman atrial natriuretic polypeptide inhibits steroidogenesis in cultured human adrenal cells. J Clin Endocrinol Metab 62: 941-944, 1986.

8. Naruse M, Obana K, Naruse K, Yamaguchi H, Demura M, Inagami $\mathrm{T}$ and Shizume K: Atrial natriuretic polypeptide inhibits cortisol secretion as well as aldosterone secretion in vitro from human adrenal tissue. J Clin Endocrinol Metab 64: 10-16, 1987.

9. Carr BR and Mason JI: The effects of alpha-human atrial natriuretic polypeptide on steroidogenesis by fetal zone cells of the human fetal adrenal gland. Am J Obstet Gynecol 159: 1361-1364, 1988.

10. Hashiguchi T, Higuchi K, Ohashi M, Minamino N, Kangawa K, Mesuo $\mathrm{H}$ and Nawata H: Porcine brain natriuretic peptide: another modular of bovine adrenocortical steroidogensis. FEBS Lett 236: 455-461, 1988 .

11. Hawata H, Ohashi M, Haji M, Takayanagi R, Higuchi K, Fujio N, Hashiguchi T, Ogo A, Nakao R, Ohnaka K and Nishi Y: Atrial and brain natriuretic peptide in adrenal steroidogenesis. J Steroid Biochem Mol Biol 40: 367-379, 1991.

12. Niina H, Kobayashi H, Yamamoto R, Yuhi T, Yanagita $T$ and Wada A: Receptors for atrial natriuretic peptide in adrenal chromaffin cells. Biochem Pharmacol 51: 855-858, 1996.

13. Kobayashi H, Niina H, Yamamoto R and Wada A: Receptor for natriuretic peptides in adrenal chromaffin cells. Biochem Pharmacol 55: 1-7, 1998.

14. Holtz J, Sommer O and Bassenge E: Inhibition of sympathoadrenal activity by atrial natriuretic factor in dogs. Hypertension 9: $350-354,1987$

15. Fernandez BE, Dominguez AE, Gonzalez MA and Okobori R: Role of atrial natriuretic peptide on calcium channel mechanisms involved in catecholamine release from bovine adrenal medulla. Arch Int Pharmacodyn Ther 316: 105-113, 1992.

16. Vatta MS, Papouchado ML, Bianciotti LG and Fernandez BE: Modulation of the rat adrenal medulla norepinephrine secretion in a sodium-free medium by atrial natriuretic factor. Peptides 15 : 709-712, 1994.
17. Babinski K, Haddad P, Vallerand D, McNicoll N, De Léan A and Ong H: Natriuretic peptides inhibit nicotine induced wholecell currents and catecholamine secretion in bovine chromaffin cells: evidence for the involvement of the atrial natriuretic factor $\mathrm{R}(2)$ receptors. J Neurochem 64: 1080-1087, 1995.

18. Takekoshi $\mathrm{K}$, Ishii $\mathrm{K}$, Isobe $\mathrm{K}$, Nomura $\mathrm{F}$, Nammoku $\mathrm{T}$ and Nakai T: Effects of natriuretic peptides (ANP, BNP and CNP) on catecholamine synthesis and TH mRNA levels in PC12 cells. Life Sci 66: PL303-PL311, 2000.

19. Hochol A. Albertin G, Nussdorfer GG, Spinazzi R, Ziolkowska A, Rucinski M and Malendowicz LK: Effects of neuropeptides B and $\mathrm{W}$ on the secretion and growth of rat adrenocortical cells. Int J Mol Med 14: 843-847, 2004.

20. Mazzocchi G, Rebuffat P, Ziolkowska A, Rossi GP, Malendowicz LK and Nussdorfer GG: G protein receptors 7 and 8 are expressed in human adrenocortical cells, and their endogenous ligands neuropeptides $\mathrm{B}$ and $\mathrm{W}$ enhance cortisol secretion by activating adenylate cyclase- and phospholipase C-dependent signaling cascades. J Clin Endocrinol Metab 90: 3466-3471, 2005.

21. Appa Rao NV, Sen NS, Sinha PD and Ahmad MF: Effect of Metenkephalin on the cortisol profile of palm squirrel (Funambulus pennanti, Wroughton). Eur Arch Biol 105: 7-11, 1994.

22. Neri G, Andreis PG, Prayer-Galetti T, Rossi GP, Malendowicz LK and Nussdorfer GG: Pituitary adenylate cyclase-activating peptide enhances aldosterone secretion of human adrenal gland: evidence for an indirect mechanism, probably involving the local release of catecholamines. J Clin Endocrinol Metab 81: 169-173, 1996.

23. Tortorella C, Macchi C, Spinazzi R, Malendowicz LK and Trejter $\mathrm{M}$ and Nussdorfer GG: Ghrelin, an endogenous ligand for the growth hormone-secretagogue receptor, is expressed in the human adrenal cortex. Int J Mol Med 12: 213-217, 2003

24. Andreis PG, Rucinski M, Neri G, Conconi MT, Petrelli L, Parnigotto PP, Malendowicz LK and Nussdorfer GG: Neuropeptides $\mathrm{B}$ and $\mathrm{W}$ enhance the growth of human adrenocortical carcinoma-derived NCI-H295 cells by exerting MAPK p42/ p44-mediated proliferogenic and antiapoptotic effects. Int J Mol Med 16: 1021-1028, 2005.

25. Ziolkowska A, Rucinski M, Neri G, Di Liddo R, Nussdorfer GG and Malendowicz LK: Expression of the beacon gene in the rat adrenal gland: direct inhibitory effect of beacon[47-73] on aldosterone secretion from dispersed adrenal zona glomerulosa cells. Int J Mol Med 13: 215-219, 2004.

26. Rucinski M, Andreis PG, Ziolkowska A, Nussdorfer GG and Malendowicz LK: Differential expression and function of beacon in the rat adrenal cortex and medulla. Int J Mol Med 16: 35-40, 2005

27. Lightly ERT, Walker SW, Bird IM and Williams BC: Subclassification of $\beta$-adrenoceptors responsible for steroidogenesis in primary cultures of bovine adrenocortical zona fasciculata/reticularis cells. Br J Pharmacol 99: 709-712, 1990.

28. Nussdorfer GG and Malendowicz LK: Role of VIP, PACAP and related peptides in the regulation of the hypothalamo-pituitaryadrenal axis. Peptides 19: 1443-1467, 1998.

29. Spinazzi R, Andreis PG and Nussdorfer GG: Neuropeptide-Y and $\mathrm{Y}$-receptors in the autocrine-paracrine regulation of adrenal gland under physiological and pathophysiological conditions. Int J Mol Med 15: 3-13, 2005.

30. Nussdorfer GG and Malendowicz LK: Role of tachykinins in the regulation of the hypothalamo-pituitary-adrenal axis. Peptides 19: 949-968, 1998.

31. Nussdorfer GG, Rossi GP, Malendowicz LK and Mazzocchi G: Autocrine-paracrine endothelin system in the physiology and pathology of steroid secreting tissues. Pharmacol Rev 51: 403-438, 1999.

32. Nussdorfer GG: Proadrenomedullin-derived peptides in the paracrine control of the hypothalamo-pituitary-adrenal axis. Int Rev Cytol 206: 249-284, 2001. 